\title{
CORPORATE ETHICS PROGRAMS AS CONTROL SYSTEMS: INFLUENCES OF EXECUTIVE COMMITMENT AND ENVIRONMENTAL FACTORS
}

\author{
GARY R. WEAVER \\ University of Delaware \\ LINDA KLEBE TREVIÑO \\ PHILIP L. COCHRAN \\ Pennsylvania State University
}

\begin{abstract}
Our study asked why corporations introduce formal programs to manage ethics and why those programs display varying characteristics. We used control theory to delineate an ethics program's scope and its orientation toward compliance- and valuesbased control. Managerial choice theory suggests that environmental factors and management's ethical commitment will influence these dimensions. Environmental factors were the stronger influences on scope, but management commitment was the stronger determinant of control orientation. Research and policy implications are discussed.
\end{abstract}

American businesses are investing in formal ethics programs (Berenbeim, 1992; Center for Business Ethics, 1992). A recent survey of large U.S. corporations found that 78 percent of responding companies had codes of ethics, 51 percent had telephone lines for reporting ethical concerns, and 30 percent had offices for dealing with ethics and legal compliance. Nearly two-thirds of those offices were created in the 1990s (Weaver, Treviño \& Cochran, in press). Corporate ethics officers now have their own professional association (the Ethics Officer Association) with members representing nearly 300 major corporations. One CEO estimated that his company spends $\$ 1$ million per year on its ethics and legal compliance programs (Barbakow, 1995).

Our study concerned the factors influencing these formal efforts to manage employees' ethical conduct. In the academic and practitioner literatures, these efforts have often been attributed to governmental pressure (Bureau of National Affairs, 1996; Rafalko, 1994; United States Sentencing Commission, 1995; Wall Street Journal, 1994). But this common focus on governmental pressure suggests a narrow and deterministic view of corporate

We thank Dennis Gioia, Martin Kilduff, and the anonymous reviewers for their helpful comments on this article. We also thank June Weaver, and Judy Sartore's staff at the research support center of the Smeal College of Business, Pennsylvania State University, for assistance with data collection. We gratefully acknowledge research support from the Ethics in Business Research Fund of the American Institute of Certified Public Accountants. ethics programs. By contrast, we propose a managerial choice perspective (Child, 1972, 1997) that highlights the active role of management, both in responding to external pressures and in taking positive action on its own. A managerial choice perspective allows for "pro-action as well as re-action" (Child, 1997: 46) and recognizes that managers enjoy " 'bounded' autonomy" (Child, 1997: 53).

We used survey and archival data from Fortune 500 companies to examine how formal ethics programs reflect external pressures and top management's own commitment to ethics. In this article, we first use control theory to identify specific dimensions over which ethics programs may vary. We then apply our choice perspective and propose that both environmental and management factors influence ethics programs' dimensions. We also propose that some dimensions of ethics programs are influenced primarily by environmental factors, but that others are influenced primarily by management.

\section{FORMAL ETHICS PROGRAMS AS CONTROL SYSTEMS: SCOPE AND CONTROL ORIENTATION}

Formal corporate ethics programs typically include some or all of the following elements: (1) formal ethics codes, which articulate a firm's expectations regarding ethics, (2) ethics committees charged with developing ethics policies, evaluating company or employee actions, and/or investigating and adjudicating policy violations, (3) ethics com- 
munication systems (e.g., telephone lines) providing a means for employees to report abuses or obtain guidance, (4) ethics officers or ombudspersons charged with coordinating policies, providing ethics education, or investigating allegations, (5) ethics training programs, aimed at helping employees to recognize and respond to ethical issues, and (6) disciplinary processes to address unethical behavior. Previous survey research has only reported on the numbers of companies engaging in these activities, without developing constructs that might help explain what these activities represent and the roles they play within companies (Berenbeim, 1992; Center for Business Ethics, 1992). Therefore, we begin by developing a conceptualization of formal ethics programs as a type of organization control system.

Control, a major responsibility of management, covers many types of behavior in a company, including ethical conduct and compliance with the law. Formal ethics programs can be conceptualized as organizational control systems aimed at standardizing employee behavior within the domains of ethics and legal compliance. As such, formal ethics control systems have goals similar to those of control systems in general: standardized behavior that allows "stable expectations to be formed by each member of the group as to the behavior of the other members under specified conditions" (Simon, 1957: 100).

\section{The Scope of Ethics Programs}

Control systems can be characterized in terms of their scope-that is, the degree to which behavioral control is achieved through formalization, specialization, and hierarchy (Bendix, 1956; Edwards, 1979; Weber, 1947). In the case of corporate ethics programs, codes of conduct and other policy documents formalize company values and expectations for ethical behavior. These policies are administered by occupants of specialized positions (e.g., corporate and divisional ethics officers, departmental ethics coordinators). Therefore, we defined the scope of a corporation's ethics program as the number of different ethics program elements included in the formal ethics management effort. In some companies, ethics programs are broad in scope, with multiple elements, including dedicated staff, supporting structures and policies, and extensive employee involvement. In other companies, the scope of ethics management is limited, with little, if any, staff and few supporting structures.

\section{Ethics Program Control Orientation}

Control systems are also characterized by their control orientation-that is, the manner in which they standardize behavior. Theorists distinguish between overtly coercive systems that rely on restraints like punishment to achieve behavioral compliance and systems that aim for member identification with and commitment to organizational goals and values (Adler \& Borys, 1996; Etzioni, 1961; Gouldner, 1954; Scott \& Meyer, 1991; Weber, 1947). Corporate ethics programs similarly can differ in control orientation. Some ethics programs embody a coercive orientation toward control that emphasizes adhering to rules, monitoring employee behavior, and disciplining misconduct. We refer to such programs as compliance-oriented (Paine, 1995). However, corporate ethics programs may also aim to standardize behavior by creating commitment to shared values and encouraging ethical aspirations (Etzioni, 1961; Paine, 1995). We refer to formal ethics programs that emphasize support for employees' ethical aspirations and the development of shared values as values-oriented. But compliance and values orientations need not be mutually exclusive (Paine, 1995; Treviño, 1990). An organization's ethics program may aim for both internalization of values and compliance with rules, so that organizational values are not perceived as empty rhetoric (Treviño, 1990).

\section{INFLUENCES ON THE SCOPE OF ETHICS PROGRAMS: ENVIRONMENTAL FACTORS AND MANAGEMENT COMMITMENT TO ETHICS}

Researchers have sought a reconciliation of the once-opposed determinism and choice positions on organizational structuring (Bourgeois, 1984; Hitt \& Tyler, 1991). For example, Hrebiniak and Joyce (1985) argued that managers may be highly constrained regarding some decisions but free in regard to others. External expectations can be uncertain or in conflict, creating interpretive latitude and opportunities for managerial discretion (DiMaggio, 1988; Goodrick \& Salancik, 1996; Oliver, 1991; Powell, 1988). In this study, we adopted a managerial choice perspective, viewing management as exercising what Child (1997) referred to as bounded autonomy. In this view, organizational structures and actions reflect both the proactive exercise of managerial discretion and reactions to real or perceived environmental expectations (Dutton \& Duncan, 1987; Weick, 1979). 


\section{Environmental Influences on the Scope of Ethics Programs}

The institutional environment is a likely influence on formal ethics programs (DiMaggio \& Powell, 1983; Meyer \& Rowan, 1977; Scott, 1995). Societal institutions often pressure organizations to conform to formal and informal standards of legitimate behavior, and some of these standards are framed in terms of ethical values or explicit expectations for ethical behavior (Suchman, 1995). Research has typically cited government agencies, professional and accrediting bodies, and interest groups or other loci of public opinion as having sufficient institutional status to influence business organizations (Elsbach \& Sutton, 1992; Galaskiewicz, 1985; Greening \& Gray, 1994). Even though the workings of these institutions can be influenced by activity on the part of businesses, such as political lobbying or the funding of nonprofit agencies, institutions also generate their own influences on business organizations.

Government. Governmental pressures form a significant element of the institutional environment of business organizations (DiMaggio \& Powell, 1983; Meyer \& Rowan, 1977; Miles, 1982; Salancik, 1979). The guidelines issued by the United States Sentencing Commission (USSC) for punishing organizational defendants have been identified as an important influence on formal ethics management (Dalton, Metzger, \& Hill, 1994; Rafalko, 1994). These guidelines, released in 1991, both (1) increased the penalties attached to convictions for illegal corporate behavior and (2) allowed for substantial reductions in penalties for offending companies that had made formal, proactive efforts to control their own ethics and ensure legal compliance (United States Sentencing Commission, 1994).

The guidelines specify seven requirements for an effective program that are characteristic of control systems (Weber, 1947). For example, organizations are expected to develop behavioral policies, assign responsibility for overseeing those policies to highlevel individuals, communicate the policies, take steps to achieve compliance, and respond to policy violations (United States Sentencing Commission, 1994). Thus, the USSC guidelines offer strong institutional support for broad-scope ethics programs with staff, codes, training programs, dedicated ethics telephone lines, and disciplinary mechanisms. However, the sentencing guidelines have not influenced all companies equally. In our interactions with senior executives from Fortune 500 companies, we were surprised at the lack of familiarity with the sentencing guidelines among some of them. Variation in key decision makers' familiarity with the USSC guidelines should influence whether their organizations implement broadscope programs consistent with the guidelines' specifications.

Hypothesis 1. The more that a company's top management is aware of the United States Sentencing Commission's guidelines, the broader the scope of its ethics program.

Media attention. Shapers of public opinion can spread legitimating and delegitimating accounts of organizations and thus influence the behavior of consumers, interest groups, government agencies, and other institutional actors (Chen \& Meindl, 1991; Elsbach \& Sutton, 1992). Media organizations in particular are in a position to exert pressure on organizations by publicizing companies' real or alleged ethical failings (Greening \& Gray, 1994; Wartick, 1992). Companies that have been the targets of critical media attention are more likely to develop visible policies and practices in an attempt to restore lost legitimacy or to ward off negative media attention in the future (Ashforth \& Gibbs, 1990). For example, several apparel marketers and retailers have developed codes and policies regarding their own and suppliers' treatment of employees following media attention to overseas sweatshops (Miller, 1997). Thus, media attention directed toward a company's ethical failings is likely to prompt the company to engage in broaderscope ethics management.

Hypothesis 2. The more media attention a company has received for its ethical failures, the broader the scope of its ethics program.

Business standard setters. Organizations are influenced by high-status fashion setters in the business world who set normative standards for a welldesigned and managed organization (Abrahamson, 1996; DiMaggio \& Powell, 1983; Scott, 1995). Formal corporate ethics programs regularly receive endorsement from standard setters such as the business press and professional associations. For example, the Conference Board, the leading business membership organization targeted toward high-level managers, holds a well-attended annual meeting on business ethics where corporate officers come to learn about ethics management. We attended the last six of these meetings, which typically offered (1) favorable descriptions of companies with broad-scope ethics programs, (2) testimonials about how broad formal ethics programs are an indication of forward-looking management, and (3) how-to-do-it sessions conducted by executives and consultants who have developed corporate ethics initiatives such as codes of con- 
duct, training programs, and disciplinary and monitoring systems. Given that the Conference Board programs endorse a variety of formal ethics initiatives, we would expect attendees to come away thinking that these initiatives are legitimate and worth implementing.

Hypothesis 3. A company's presence at Conference Board ethics meetings will lead to its adoption of a broader-scope ethics program.

\section{The Influence of Top Management Commitment on the Scope of Ethics Programs}

Executives can act both proactively and reactively (Child, 1997), exercising choice in addition to responding to real or perceived external expectations (Child, 1972; Hitt \& Tyler, 1991; Hrebiniak \& Joyce, 1985; Oliver, 1991). An executive's exercise of choice is influenced in part by characteristics of the executive (Finkelstein \& Hambrick, 1990, 1996; Hambrick \& Finkelstein, 1987). According to upper echelons theory (Hambrick \& Mason, 1984), executives have cognitive frameworks and value commitments that influence organizational outcomes. The value commitments of top executives are particularly important because these officers have the status necessary to influence organizational actions (Finkelstein \& Hambrick, 1990, 1996). We propose that executives who are strongly committed to ethics will influence their organizations to develop formal ethics programs. This view is consistent with the business ethics literature, which stresses the importance of executives' commitment to ethics (Paine, 1996).

The point might best be illustrated with an example: Robert Haas, CEO of Levi Strauss \& Company (Business Week, 1994; Haas, 1994: Howard, 1990) has been described as wanting the corporation to profit and to make the world a better place, and he supports that outlook by requiring that corporate "aspirations" guide all decisions (Business Week, 1994: 46). As a young adult, Haas marched for civil rights, served in the Peace Corps, served in the White House in the Johnson administration, and worked as a McKinsey \& Company consultant, where he was known as an environmentalist (Sherman, 1997). Haas's ethical commitment appears to have influenced Levi Strauss's development of an aspirations statement, diversity programs, ethics initiatives, and child labor policies for overseas suppliers (Levi Strauss \& Company, 1997a, 1997b).

If asked, most top managers would likely agree that they are committed to ethics. But commitment to ethics can easily be lost in an environment in which managers are expected to deliver increasing returns to shareholders and stay ahead of the competition. Executives have to decide how to spend their limited time and what messages to send to employees. Many executives' messages to employees focus primarily on meeting bottom-line goals. But executives who have a personal commitment to ethics also regularly express concern about how companies' goals are achieved (Haas, 1994; Howard, 1990), and they communicate concern about their companies' nonfinancial obligationsobligations to do the right thing, treat people fairly, and be a good member of society. A top manager who is committed to ethics is also likely to consider an investment in ethics programs, policies, and structures to be an important way to demonstrate and symbolize that commitment.

Hypothesis 4. The more strongly a company's top management is committed to ethics, the broader the scope of its ethics program.

\section{Relative Influences of the Environment and Top Management Commitment on the Scope of Ethics Programs}

There is little room for exercising managerial discretion in an organization if external expectations are clear and the means to be used to achieve those ends are specified (Goodrick \& Salancik, 1996). But uncertainty in external expectations leaves room for managerial discretion (Covaleski \& Dirsmith, 1988; DiMaggio, 1988; Oliver, 1991). The USSC guidelines are clear and specific about the formal ethics program elements that are required if organizations are to benefit from reduced penalties. Thus, under the USSC guidelines, management is relatively constrained in choosing the number of ethics program elements to implement (that is, constrained as to scope). Conference Board meetings also create expectations that companies will engage in broad-scope ethics management, as the meetings present companies with broad ethics programs as exemplars (for instance, defense contractors' programs). Media coverage of a firm's ethical failings may not specify particular actions to take, but it does encourage visible organizational responses that symbolize that ethical issues are being addressed (Ashforth \& Gibbs, 1990; Meyer \& Rowan, 1977). In response to media attention, a company is likely to adopt multiple ethics program elements so as to clearly signal its commitment to ethics.

Environmental influences, then, are relatively clear in both the end that is proposed (ethical corporate behavior) and the means that are considered appropriate for achieving that end (broadscope ethics program structures). Failure to 
conform to external expectations exposes an organization to the risk of serious consequences in terms of lost legitimacy, imposition of sanctions, and reduced cooperation from social actors important to organizational survival. Although top management's commitment to ethics should also influence an ethics program's scope, it is more easily subject to negotiation and limitation in the face of other organizational goals and constraints, and thus should be a weaker influence on ethics program scope.

Hypothesis 5. Environmental influences will account for more variance in the scope of ethics programs than will top management's commitment to ethics.

\section{INFLUENCES ON THE CONTROL ORIENTATION OF ETHICS PROGRAMS}

\section{Environmental Pressures on the Control Orientation of Ethics Programs}

We proposed earlier that environmental factors had a powerful influence on ethics programs' scope because only a broad-scope program would satisfy relatively clear environmental expectations. However, environmental expectations are more ambiguous regarding the control orientation of ethics programs. Conference Board sessions tend to focus on the different types of initiatives (codes, training, hotlines, etc.) that compose a complete ethics program rather than on recommendations about particular control orientations within these activities. But ethics initiatives can be either values or compliance oriented. An ethics code, for example, can emphasize either shared values or regulations and the penalties for breaking them. Also, media attention to a company's ethical failings often does not prescribe how to remedy problems. As long as the company takes action that appears to satisfy societal expectations, the company may enjoy latitude regarding just how it responds. Also, little research exists to support the effectiveness of one ethics program control orientation over another. Thus, environmental pressures that are relatively strong in relation to scope may be weaker when it comes to control orientation (Goodrick \& Salancik, 1996).

We propose that management's awareness of the USSC guidelines is the only measured environmental factor that will influence an ethics program's control orientation and that this awareness will influence organizations to adopt a compliance orientation. The USSC guidelines are clearly aimed at legal compliance (obeying the rules), and they stress the prevention and detection of offenses (United States Sentencing Commission, 1994; Sec- tion 8.K). The guidelines contain complianceoriented language, referring, for instance, to "compliance standards and procedures" rather than to "ethics programs" (United States Sentencing Commission, 1994, 1995). They recommend that companies adopt monitoring, auditing, and reporting systems for detecting illegal conduct. Finally, they stress discipline for employees who violate policies and for managers who fail to detect offenses committed by others (United States Sentencing Commission, 1994; Section 8.A.1.2). In short, the guidelines foster a control orientation focused on rules, monitoring, and discipline.

Hypothesis 6. The more a company's top management is aware of the United States Sentencing Commission guidelines, the more its formal ethics program will be compliance oriented.

\section{The Influence of Top Management Commitment on the Control Orientation of Ethics Programs}

Executives who are committed to ethics are likely to encourage a values-oriented approach to ethics management. Managers often project their own attitudes onto others (Mowday, 1982), and executives who are committed to ethics may project that outlook onto other organization members. Thus, they will expect organization members to respond to aspirational appeals to "do the right thing" (Treviño, 1990). Their goal will be to foster employee identification with and commitment to a set of shared ethical values. For example, the Levi Strauss \& Company aspirations statement reflects CEO Haas's concern for people and projects that attitude onto other organization members: "We all want a Company that our people are proud of and committed to.... We want our people to feel respected, treated fairly, listened to and involved" (Levi Strauss \& Company, 1997c; emphasis added). When executives are strongly committed to ethics, ethics programs should display an orientation that encourages employees to internalize and act on a set of values.

But values and compliance orientations are not mutually exclusive (Paine, 1995). Executives who are committed to ethics will also influence their organizations to adopt a compliance orientation. When executives take ethical issues seriously, they recognize the need to support ethical talk with actions. They are attentive to the justice concerns that can arise-specifically, to employees' expectations that all employees will be held to agreedupon standards and that misconduct will be punished (Lerner, 1977; Treviño, 1993; Treviño \& Ball, 1992). These expectations about accountability 
should engender a willingness to take and support compliance-oriented actions such as discipline for offenses. Thus, although environmental factors (USSC requirements) will have a limited influence on the control orientation of ethics programs (encouraging a compliance orientation), we propose that top management commitment will have a more comprehensive impact, affecting both compliance and values orientations.

Hypothesis 7. The more strongly a company's top management is committed to ethics, the more its ethics program will be both compliance oriented and values oriented.

\section{The Relative Influences of Environment and Top Management Commitment on the Control Orientation of Ethics Programs}

Although the USSC guidelines support a compliance approach toward control, they do not specify how strongly developed this orientation should be, and they do not exclude a complementary values orientation. For example, instead of defining the exact details of an ethics program, the guidelines simply stipulate that companies adopt monitoring, auditing, and disciplinary mechanisms that are "adequate," "reasonable," and "effective" (United States Sentencing Commission, 1994; Section 8.A.1.2). Thus, management retains latitude to determine just how strongly compliance-oriented an ethics program will be and how much the program's compliance aspects will be joined to valuesoriented elements. This latitude for management discretion is to be expected given the lack of a developed knowledge base addressing effectiveness in ethics programs. The lack of conventionally accepted means for achieving a desired goal makes it difficult for external actors to specify exactly how organizations should satisfy their expectations, leaving much room for management discretion (Goodrick \& Salancik, 1996). In these circumstances, executives who are committed to ethics have reasons to pursue specific control orientations and also enjoy the discretion to do so.

Hypothesis 8. Top managements' commitment to ethics will account for more variance in the control orientation of ethics programs than will environmental influences.

\section{METHODS}

\section{Population and Data Sources}

The population studied consisted of all of the Fortune 500 Industrial and Fortune 500 Service companies listed for 1994. Data were obtained from survey and archival sources, including (1) a mail survey of officers knowledgeable about company ethics practices, (2) registration lists for Conference Board ethics meetings, and (3) a database of article abstracts from 25 major U.S. newspapers for the period 1989-1994.

Previous research suggested that for some organizational phenomena, a particular high-level corporate officer specializing in those phenomena provides the most accurate information (Thomas, Clark, \& Gioia, 1993). We targeted company officials who would be most familiar with any formal efforts their organizations might be making to deal specifically with ethics. Using the National Directory of Corporate Public Affairs, we telephoned a representative in the public affairs or corporate communications departments of each of the 1,000 companies in our population in order to identify the high-ranking officer who could best describe the company's formal ethics activities, if any. We used a common script, asking for the name of "the officer most responsible for dealing with ethics and conduct issues in the company." (Where a company did not have a listing in the National Directory of Corporate Public Affairs, the call was directed to the company's human resources department.) We framed our query in terms of "ethics and conduct issues" rather than "programs" as we did not expect that all responding companies would have formal programs. Rather, we merely assumed that each company would have someone to whom responsibility for ethics issues fell by default but not necessarily someone who supervised a formal ethics program.

We generated a mailing list of individual informants at 990 companies. During late 1994, each informant was sent a questionnaire and up to two follow-up mailings. The return of 254 questionnaires represented a response rate of 26 percent. This response rate is reasonable given the ranks of the respondents: 57 percent were vice presidents or higher-level executives, and another 24 percent identified themselves as department heads (cf. Hambrick, Geletkanycz, \& Fredrickson, 1993). Eighty-six percent of the respondents identified their functional areas. Of these, only 16 percent were located in separate ethics or compliance departments; 22 percent were in legal departments; 6 percent had general high-level administrative functions, such as corporate secretary; 28 percent were in human resources; 6 percent were in public affairs or corporate communications; 11 percent were in auditing or other internal control departments; 6 percent had combined legal and corporate secretary functions; and 5 percent were in various other de- 
partments. The respondents' average age was 48 years (s.d. $=8.35$ ), and 78 percent were men. The average respondent had been with his or her company for 15 years (s.d. $=9.85$ ) and in his or her current position for 5 years (s.d. $=4.40)$.

\section{Bias Issues}

We conducted conventional tests of response bias by analyzing response rates across the service and industrial classifications in the Fortune rankings. Responding companies represented a diverse range of industries (99 different three-digit Standard Industrial Classification [SIC] categories and 41 different two-digit SIC categories). There was no significant difference in the response rates of service and industrial companies. Researchers have considered the impact of financial condition on improper corporate behavior (Baucus \& Near, 1991; Cochran \& Nigh, 1987). Therefore, we also measured potential nonresponse bias by comparing responding companies with an approximately equal number of randomly selected nonresponding companies on several financial characteristics (gross revenue, net profit, total assets, return on sales, return on assets) and on size, measured as number of employees. We found no significant differences between responding and nonresponding companies on any financial measure. After removing three large outlier respondents with 250,000 to 500,000 employees each, we also found no significant difference on size.

It is possible that companies with minimal formal ethics management activities would have been less likely to respond. However, descriptive statistics indicated that the sample varied widely on formal ethics program activity. For example, the median company on our ethics program scope measure (described in detail below) had an officer who devoted only 15 percent of his or her time to ethics. The company had a written ethics policy but no ethics telephone line, no ethics or compliance office, no ethics committees, and no ongoing ethics follow-up with employees. Half of our responding companies, then, only did this much or less to formally address ethics issues. Thus, the data set incorporated sufficient variance for analyzing the influences driving corporate ethics program characteristics.

Social desirability bias is a risk in any ethicsrelated study (Fernandes \& Randall, 1992; Moorman \& Podsakoff, 1985). We tried to minimize socially desirable responses by ensuring that our survey clearly did not focus on companies' "dirty laundry" or on the effectiveness of their ethics initiatives. Informants were told that the questions concerned formal policies, procedures, and organizational characteristics and that the study was an effort to see how companies' ethics activities, if any, varied to fit different organizational situations. We also attempted to minimize bias through the wording of the survey items addressing the scope of ethics programs. Many of these items were written in objective, yes/no fashion (e.g., "Does your firm have an ethics committee?"), and nondichotomous items were given multiple descriptive anchors.

Nevertheless, it remained possible that company informants would be self-serving in their responses. But prior to constructing our questionnaire, we completed structured interviews with 20 ethics-responsible officers in a variety of companies. These officers were quite candid about what their companies were not doing in regard to ethics and about varying degrees of top management support for ethics-related activities. These responses suggested to us that we would receive reasonably realistic reports from ethics-responsible officers in the sampled firms. Further, survey respondents were likely not personally invested in particular ethics-oriented roles. Only 54 percent of the responding companies indicated assigning ethics responsibilities specifically to one officer. More than half of these officers $(65 \%)$ spent no more than 20 percent of their time on ethics-related activities, and only 18 percent showed a close to full-time commitment (over 80 percent of their time) to ethics activities. For most respondents, ethics activities did not constitute a personal empire whose maintenance might prompt self-serving responses.

\section{Dependent Variable Measures}

Ethics program scope. The scope of formal ethics activities was measured with survey items that asked objective questions about a company's ethics structures and activities. These included questions about the presence of a code of ethics or other ethics policy documents, the extent of the distribution of those policies to employees, the presence and staff size of special ethics offices and committees, the frequency with which various levels of employees received ethics-oriented communications and training, and the use of dedicated ethics telephone lines. These items were answered in yes/ no, percentage, or Likert-scale formats. We formed a composite measure of ethics program scope by summing the $Z$-scores of all the items. Higher scores on the scope measure reflected the presence of more ethics-oriented structures and activities.

Ethics program mode of control. The degree to which a values orientation and a compliance orientation characterized an ethics program's mode of 
control was measured according to the reported emphases in the program on values and aspirations and on monitoring and punishment. To measure the extent of a program's values orientation, we used four Likert-type items, assessing ethics programs' emphases on (1) encouraging shared values, (2) supporting employee aspirations, (3) communicating company values, and (4) building trust and confidence. A sample item is "How prominent is the activity of encouraging shared values in the firm's overall effort to foster good ethics?" $(\alpha=.80)$. To measure the extent of a program's compliance orientation, we used six items assessing the prominence of (1) discipline for nonconformity, (2) investigation of complaints, and (3) auditing for compliance. A sample item is "How prominent is the activity of investigating complaints in the firm's overall effort to foster good ethics?" $(\alpha=.84)$. Factor analysis with "varimax" rotation resulted in two factors explaining 59 percent of the variance (see Table 1): compliance orientation (eigenvalue $=$ 4.15 ) and values orientation (eigenvalue $=1.78$ ).

\section{Independent Variables}

Top management's awareness of USSC guidelines. We used three survey items to measure executives' awareness of the U.S. Sentencing Commission's guidelines $(\alpha=.88)$. These five-point Likerttype items queried the extent to which top management meetings and communications addressed the impact of the guidelines and the respondent's knowledge of the guidelines; an example is "High-level managers in this firm have discussed the 1991 U.S. Corporate Sentencing Guidelines" ( $5=$ strongly agree, $1=$ strongly disagree). Descriptive data for this measure indicated that managers varied in awareness of the guidelines and their requirements $(\bar{x}=3.26$, s.d. $=1.17)$.

Media attention to company's ethical findings. We measured media attention to a firm's ethical failings by using the database Newspaper Abstracts, which covers 25 regional and national newspapers. For each responding company, we summed the number of article abstracts in the database that suggested ethical failure at the company. The time period covered ranged from 1989 (the first year in the database) through October 1994 (the start of our survey period). Using the same written guidelines, two trained research assistants (each covering about half of responding companies) counted abstracts indicating (1) violation of the law (conviction for or accusation of antitrust activities, insider trading, discriminatory hiring, fraud, and so forth), (2) harm or threat to the public generally or to specific innocent bystanders (for instance, accusations of poor safety at chemical or nuclear facilities, inattention to safety in aircraft design or maintenance), (3) allegedly ruthless business practices, or (4) suggestions of undisclosed corporate impropriety (for instance, the suicide of an officer at a company under investigation). One of the authors repeated the abstract search for 10 percent of the companies evaluated by each research assistant. Using the conservative $P$-statistic (Light, 1971), we obtained interrater agreement between the author and the two research assistants of 71 and 70 percent.

Presence at Conference Board meetings. We used conference registration lists to measure a company's representation at the three ethics meetings the Conference Board held prior to administration of our survey (these were in 1992, 1993, and 1994). A company was considered to have been repre-

TABLE 1

Rotated Factors and Loadings for Ethics Programs' Control Orientations ${ }^{\text {a }}$

\begin{tabular}{lcc}
\hline \multicolumn{1}{c}{ Items } & Factor 1: Compliance & Factor 2: Values \\
\hline Employees violating ethics expectations are disciplined. &. $\mathbf{8 7}$ & .10 \\
Employee failing to abide by policies will be disciplined. &. $\mathbf{. 6}$ &. $\mathbf{. 6}$ \\
People not conforming to ethical standards are disciplined. &. $\mathbf{6 6}$ \\
Even minor violations of ethical expectations get an employee disciplined. &. $\mathbf{6 4}$ \\
Auditing for compliance with law is prominent in company's ethics activities. &. $\mathbf{5 7}$ \\
Investigating complaints is prominent in company's ethics activities. & .04 \\
Ethics activities and policies are oriented toward building trust and confidence. & .08 \\
Ethics activities and policies are oriented toward communicating the company's values. & .24 \\
Encouraging shared values is prominent in company's ethics activities. & .34 \\
Supporting employee goals and aspirations is prominent in company's ethics activities. & .15 \\
Eigenvalue & $\mathbf{. 3 4}$ \\
\hline
\end{tabular}

\footnotetext{
${ }^{\text {a }}$ Factor loadings greater than .50 are bold.
} 
sented if one or more of its members appeared on the list for one or more of the three conferences. We did not use the total number of conference attendees from a company so as to not bias the data in favor of companies located close to the New York City conference site. We used a three-year period to allow for the fact that companies might not have been able to participate every year.

Top management's commitment to ethics. Measurement of top management commitment to ethics raised social desirability concerns (Fernandes \& Randall, 1992). Executives' reports about their own ethical commitments would likely be subject to social desirability biases. However, our informants would be able to assess how much top management was concerned with ethics by noting the amount of attention paid to ethics in high-level discussions. The attention paid to topics in high-level discussions should be an indication of what top management thinks is important. Therefore, we gave informants a list of potential topics of top management conversation. Some of the topics suggested that executives viewed ethics as intrinsically valuable (for instance, "valuing integrity as much as profits," "doing the right thing," "seeking the good of society"; see Table 2), and others were performanceoriented topics to which one also would expect managements to show commitment (e.g., finances, strategy, operational problems). We introduced the list by telling informants that we wanted them to assess "the overall business orientation of your firm's top management by [rating] the extent to which various subjects are a topic of conversation for your firm's top management team (i.e., executive vice presidents and higher)." They then saw the list of the various conversation topics, each of which they rated on five-point Likert scales ranging from "never" to "very frequently." The more highly

TABLE 2

Factor Loadings for Management Commitment to Ethics

\begin{tabular}{lc}
\hline \multicolumn{1}{c}{ Items } & $\begin{array}{c}\text { Factor 1: } \\
\text { Commitment } \\
\text { to Ethics }\end{array}$ \\
\hline Seeing that justice is done & .83 \\
Doing the right thing & .79 \\
Valuing integrity as much as profits & .76 \\
The company's role in society & .75 \\
Treating people fairly & .74 \\
Nonfinancial and nonlegal obligations & .73 \\
Seeking the good of society & .71 \\
The importance of self-restraint & .64 \\
Eigenvalue & 4.44 \\
\hline
\end{tabular}

a management was rated on items suggesting the intrinsic value of ethics, the more we considered that management committed to ethics. The performance items functioned as foils. They were expected to dissuade informants from uncritically giving high rankings to the ethics-related items; for example, the taken-for-granted importance of finances might force ethics out of the highest category.

A principal components factor analysis of eight items assessing management's commitment to ethics generated one factor explaining 55 percent of the variance (eigenvalue $=4.44$; see Table 2 ). Reliability analysis of the eight items yielded a Cronbach's alpha of .88 . The mean for these items was 3.43 (s.d. $=0.75$, range $=1-5$, where 5 denotes very frequent discussion of the topic). By contrast, the mean for the performance foils was 4.56 (s.d. = 0.52 , range $=2.67-5.00$ ). This pattern indicates relatively low and varied responses for top management commitment to ethics; respondents in effect were willing to admit that questions of ethics did not receive the same degree of top management attention as strategic and financial concerns.

Control variables. We controlled for the effect of financial performance and company size. We measured financial performance as a company's return on assets (ROA) relative to its industry's ROA, defining industries in terms of responding companies' two-digit primary SIC classifications and obtaining data from Compact Disclosure. Financial performance was averaged оver a three-year period (fiscal year [FY] 1992 through FY 1994). Size was measured as total number of employees, using the employee totals provided in the Fortune 500 listings.

\section{Analyses}

Because of significant correlations among the dependent variables, we used an omnibus test of significance for the overall model. Canonical correlation analysis of all three dependent variables and all independent and control variables generated a significant overall model (Wilks's $\lambda=.37, p<.01$ ). We then relied on hierarchical regression analysis to test Hypotheses 1 through 4 and 6 and 7.

Hypothesis 5 proposed that environmental influences would account for more variance in the scope of ethics programs than would top management's commitment to ethics. The unique contribution to variance explained by a single independent variable can be assessed by noting its squared semipartial correlation. But we were interested in comparing a single predictor-top management commitment to ethics - with a set of environmental 
influences. Therefore, we tested Hypothesis 5 with a usefulness analysis (Darlington, 1968). Usefulness analysis reveals the unique contribution of one or more independent variables to predicting a dependent variable's variance. Specifically, it provides the incremental change in explained variance that is attributable to a set of one or more independent variables and that goes beyond the contribution to explained variance of all other variables. The process compares the squared multiple correlation $\left(R^{2}\right)$ associated with each set of predictor variables while removing any variance shared by the predictor(s) in question and the other independent variables. Each set of one or more predictor variables is entered into a hierarchical regression equation in separate stages, in each possible ordering, so that it can be seen how much variance in excess of the explanatory capacity of all other variables each set of variables explains. At each stage, the amount of incremental variance explained by the newly added set of variables is observed and tested for significance, a process that reveals the unique variance (if any) attributable to each set of independent variables.

\section{RESULTS}

Table 3 reports means, standard deviations, and correlations for all variables. Table 4 reports results of hierarchical regression analyses for each dependent variable.

\section{Influences on the Scope of Ethics Programs}

The control variablus, size and financial performance, accounted for 4 percent of the variance in scope (scope equation 1). The complete model accounted for 32 percent of the variance in scope (scope equation 2).

Management's awareness of the USSC guidelines was significantly and positively linked to the scope of an ethics program (Hypothesis 1: $t=5.54, p<$ .01). Media attention to a firm's ethical failures was also significantly and positively related to scope (Hypothesis 2: $t=2.34, p<.05$ ), as was a company's presence at a Conference Board ethics meeting (Hypothesis 3: $t=4.54, p<.01$ ). Top management's commitment to ethics was also significantly and positively related to ethics program scope (Hypothesis $4: t=3.31, p<.01$ ). Thus, Hypotheses 1 through 4 were supported.

Management's commitment to ethics and the set of environmental variables (USSC awareness, media attention, and Conference Board representation) each predicted statistically significant variance in scope beyond that accounted for by the other. But the set of environmental influences significantly explained 23 percent more variance than was explained by management's commitment to ethics; when the environmental influences were added to an equation already containing controls and top management commitment, the change in $R^{2}$ was $.23(F=25.84, p<.01)$. By contrast, management's commitment to ethics explained only 3 percent more variance in scope than did environmental influences; when management commitment was added to an equation already containing controls and the three environmental influences, the change in $R^{2}$ was .03 $(F=11.00, p<.01)$. These results support Hypothesis 5 . The first column of Table 5 summarizes these findings and also provides the unique contribution to

TABLE 3

Descriptive Statistics and Correlations ${ }^{a}$

\begin{tabular}{|c|c|c|c|c|c|c|c|c|c|c|c|}
\hline Variable & Mean & s.d. & $\alpha$ & 1 & 2 & 3 & 4 & $\mathbf{5}$ & 6 & 7 & 8 \\
\hline 1. Ethics program scope & 0.00 & 8.91 & & & & & & & & & \\
\hline 2. Compliance orientation & 4.05 & 0.69 & .84 & $.23^{* *}$ & & & & & & & \\
\hline 3. Values orientation & 3.94 & 0.81 & .80 & $.26^{\star *}$ & $.39 * *$ & & & & & & \\
\hline 4. Company's size & 26,010 & 49,010 & & $.20^{* *}$ & .13 & .12 & & & & & \\
\hline 5. Financial performance ${ }^{b}$ & 1.09 & 4.93 & & -.04 & -.04 & -.05 & .04 & & & & \\
\hline $\begin{array}{l}\text { 6. Top management's awareness } \\
\text { of USSC guidelines }\end{array}$ & 3.26 & 1.17 & .88 & $.40^{* *}$ & $.24 * *$ & $.15^{*}$ & .08 & -.01 & & & \\
\hline $\begin{array}{l}\text { 7. Top management's commitment } \\
\text { to ethics }\end{array}$ & 3.43 & 0.75 & .88 & $.25^{* *}$ & $.37 * *$ & $.64 * *$ & .11 & -.03 & .12 & & \\
\hline $\begin{array}{l}\text { 8. Media attention to company's } \\
\text { ethical failings }\end{array}$ & 19.65 & 42.58 & & $.31 * *$ & .09 & $.13^{*}$ & $.40^{* *}$ & $-.06^{*}$ & $.14^{*}$ & $.16^{*}$ & \\
\hline $\begin{array}{l}\text { 9. Company's presence at Conference } \\
\text { Board meeting }\end{array}$ & 0.23 & 0.42 & & $.37 * *$ & .08 & .06 & $.16^{* *}$ & .01 & $.22 * \star$ & .04 & $.25 * *$ \\
\hline
\end{tabular}

a $N$ ranges from 242 to 254 .

b Three-year industry-weighted return on assets.

${ }^{*} p \leq .05$

${ }^{* *} p \leq .01$ 


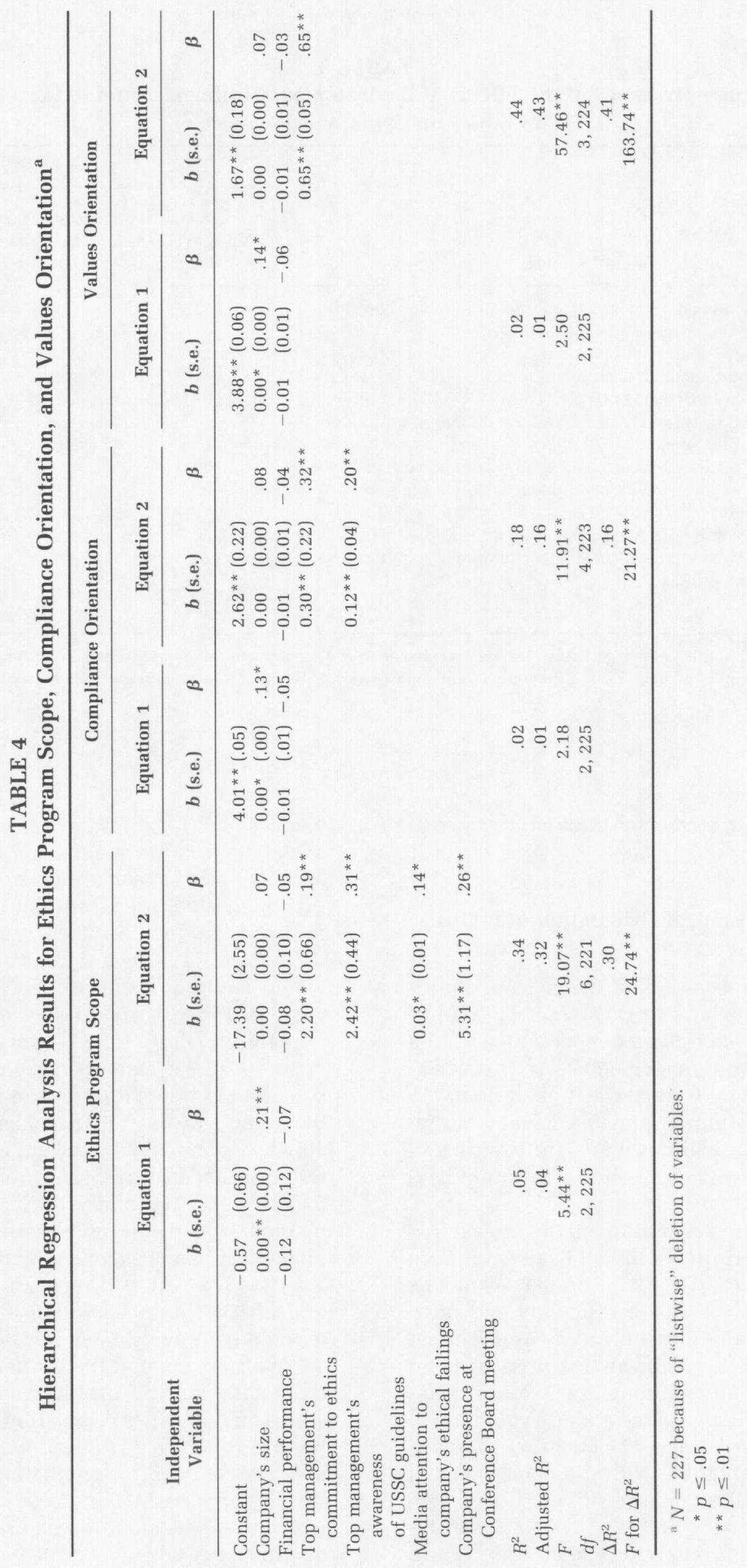


TABLE 5

Results of Usefulness Analyses of the Effects of Environmental Influences and Management Commitment to Ethics on Explained Variance ${ }^{a}$

\begin{tabular}{|c|c|c|c|}
\hline \multirow[b]{2}{*}{ Independent Variables } & \multicolumn{3}{|c|}{ Dependent Variables } \\
\hline & $\begin{array}{l}\text { Ethics Program } \\
\text { Scope }\end{array}$ & $\begin{array}{l}\text { Ethics Program } \\
\text { Compliance } \\
\text { Orientation }\end{array}$ & $\begin{array}{l}\text { Ethics Program } \\
\text { Values } \\
\text { Orientation }\end{array}$ \\
\hline $\begin{array}{l}\text { Variance explained by top management's commitment to ethics beyond that } \\
\text { explained by environmental pressures }\end{array}$ & $.03^{* *}$ & $.10^{* *}$ & $.38^{* *}$ \\
\hline $\begin{array}{l}\text { Variance explained by set of all environmental pressures beyond that } \\
\text { explained by top management's commitment to ethics }\end{array}$ & $.23^{* *}$ & $.04 * *$ & .01 \\
\hline $\begin{array}{l}\text { Variance explained by top management's awareness of USSC guidelines } \\
\text { beyond that explained by top management's commitment to ethics and } \\
\text { other environmental pressures }\end{array}$ & $.09 * *$ & .04 ** & .01 \\
\hline $\begin{array}{l}\text { Variance explained by media attention to company's ethical failings beyond } \\
\text { that explained by top management commitment to ethics and other } \\
\text { environmental pressures }\end{array}$ & $.02 * *$ & .00 & .00 \\
\hline $\begin{array}{l}\text { Variance explained by company's presence at Conference Board meeting } \\
\text { beyond that explained by top management's commitment to ethics and } \\
\text { other environmental pressures }\end{array}$ & $.06^{* *}$ & .00 & .00 \\
\hline$R^{2}$ for complete model ${ }^{\mathrm{b}}$ & $.34^{* *}$ & $.18^{\star *}$ & $.44^{* *}$ \\
\hline
\end{tabular}

${ }^{\text {a }}$ Statistics presented in the table provide the incremental change in $R^{2}$ that a given independent variable or set of independent variables accounts for (independent of what all other independent and control variables account for) and the significance of that incremental change in $R^{2}$.

${ }^{b}$ Model includes control variables.

** $n \leq n 1$

explained variance of each of the three environmental variables.

\section{Influences on the Control Orientation of Ethics Programs}

The set of control variables showed no significant relationship to an ethics program's compliance orientation (compliance equation 1). The complete model (compliance equation 2) was significant, explaining 16 percent of the variance in compliance orientation. Top management's awareness of the USSC guidelines was significantly and positively related to a compliance orientation $(\mathrm{Hy}-$ pothesis 6: $t=3.23, p<.01$ )

Top management's commitment to ethics was significantly and positively linked to a compliance orientation $(t=5.21, p<.01)$. Top management's commitment to ethics was significantly and positively linked to a values orientation as well. The set of controls showed no significant relationship to an ethics program's values orientation (values equation 1). The complete model (values equation 2) was significant, explaining 43 percent of the variance in values orientation, with top management's commitment to ethics being positively linked to a values orientation $(t=12.80, p<.01)$. Taken together, these results support Hypothesis 7: top management's commitment to ethics influences the extent to which a company's ethics program has both compliance and values orientations.

Hypothesis 8 proposed that management's commitment to ethics would play a larger role in predicting ethics program control orientations than would environmental influences. The middle column of Table 5 provides results supporting this hypothesis. Both USSC awareness and commitment to ethics explained significant variance in compliance orientation beyond that explained by the other. However, management's commitment to ethics explained 10 percent more variance than was explained by USSC awareness $\left(R^{2}=.10, F=\right.$ $27.18, p<.01$ ), and USSC awareness only explained 4 percent more variance than was explained by management's commitment $\left(R^{2}=.04\right.$, $F=10.45, p<.01$ ). There was no significant relationship between a compliance orientation and any of the other environmental influences.

We also compared the influence of environmental factors and top management's commitment to ethics on the values orientation of ethics programs. We did this in part to examine Hypothesis 8 over both types of control orientation, and also because correlational results indicated that USSC awareness and media attention had small but significant relationships with the values orientation of ethics 
programs (Table 3). Results presented in the third column of Table 5 show that management's commitment to ethics uniquely and significantly explains a substantial portion of total variance beyond that explained by the set of environmental influences $\left(R^{2}=.38, F=149.48, p<.01\right)$ but that the set of environmental influences does not predict significant variance in values orientation beyond that predicted by management commitment $\left(R^{2}=.01, F=1.31\right.$, n.s. $)$. Thus, top management commitment has a stronger influence on the control orientation of ethics programs than do the measured environmental influences (Hypothesis 8).

\section{DISCUSSION}

The findings supported our hypotheses predicting that multiple environmental influences (awareness of USSC guidelines, media attention to a firm's ethical problems, and representation at Conference Board meetings) and executive commitment to ethics would be associated with the scope of ethics programs. Moreover, the set of environmental influences was more strongly associated with ethics program scope than was executive commitment to ethics. The data also supported our hypotheses related to the control orientation of ethics programs. Both top management's awareness of the USSC guidelines and its commitment to ethics were associated with an ethics program's having a compliance orientation, and top management's commitment to ethics was associated with the extent of a program's values orientation. But top management's commitment to ethics was more strongly related to a program's control orientation than were environmental influences.

\section{Contributions to the Business Ethics Literature}

Conceptualizing formal ethics programs as control systems. Normative and theoretical business ethics research has often suggested the value of corporate ethics programs (e.g., Donaldson \& Preston, 1995; Jones, 1995), but this research either has treated ethics programs in a holistic fashion or has focused on individual program elements (e.g., codes of conduct). Empirical studies of ethics programs have been limited to atheoretical surveys that treat programs in terms of their separate elements, investigating how many firms have ethics officers, codes, ethics telephone lines, and so forth (Berenbeim, 1992; Center for Business Ethics, 1992). By conceptualizing formal ethics programs in terms of organizational control theory, the present study provides a basis for creating theoretically relevant dimensions of ethics programs. Fu- ture research can relate these dimensions to ethics program outcomes. For example, do broad-scope programs lead to greater employee awareness of ethical issues? Does a values orientation lead to less unethical behavior, as some have suggested (e.g., Paine, 1995), or is a compliance orientation or a combined compliance and values orientation most effective?

Conceptualizing ethics programs in terms of organizational control systems was consistent with our focus on formal programs. However, we acknowledge that this is a limited view of organizational ethics. We consciously chose not to focus on more informal modes of control, such as informal norms and organizational culture (Ouchi, 1980; Wilkins \& Ouchi, 1983). These more informal modes of control are likelv to be important in many organizations, especially smaller ones. We also do not claim that ethics programs should be conceptualized exclusively as control systems, as these programs might play other important roles. For example, they might play a largely symbolic role, signaling organizational legitimacy to external actors without actually influencing employee behavior. Or, serving a function closer to our concern with the control dimensions of ethics programs, they also might be understood as solutions to agency and transaction cost problems (Weaver, 1992). We urge future researchers to address these issues.

Finally, our study does not address the ethical propriety of formal ethics programs. Normative theorists may wish to evaluate whether ethics programs of various types operate in an ethically proper fashion. In most research on business ethics, ethics programs are taken at face value and treated as the ethically proper means by which companies achieve ethical ends. But if ethics programs are types of organizational controls, it is possible that they, like other controls, can be used for unethical purposes (Braverman, 1974).

Environmental influences, executive discretion, and ethics program characteristics. This study also contributes to business ethics research by showing that formal ethics program dimensions reflect multiple influences. Although how environmental and managerial factors influence organizational structures and activities has been considered in other streams of organizational study, these perspectives have not been used to understand ethics management. It is often assumed, for example, that most firms adopt ethics programs primarily as a response to the USSC guidelines (Rafalko, 1994; United States Sentencing Commission, 1995). Our study provides the first systematic empirical support for this claim but also demonstrates that (1) 
other environmental factors are important and (2) environmental factors have different influences on different dimensions of ethics programs.

Popular (Business Week, 1994) and academic (Paine, 1996; Treviño, 1990) writings have stressed the importance of the "tone at the top"-top management support for ethics-related activities. Our study provides the first systematic empirical support for this proposition by demonstrating that top managers' commitment to ethics is associated with both the scope and the control orientation of their companies' ethics programs but is particularly important for control orientation. In combination, these findings suggest that environmental factors influence organizations to initiate a broad range of formal ethics-related activities such as codes, training programs, and telephone lines. But much of the guidance for how programs are implemented comes from a firm's top managers and their commitment to ethics. Thus, management's moral outlook must be viewed as an important influence on an organization's ethical structures and practices (Etzioni, 1988; Freeman, 1995).

Our findings about the relative influences of environmental factors and executive commitments are consistent with Goodrick and Salancik's (1996) observation that uncertainty in environmental expectations increases managerial discretion. We argued that uncertainty is lower regarding environmental expectations for the scope of ethics programs and higher for ethics programs' control orientation. Therefore, we expected that top management's commitment to ethics would more strongly influence control orientation and that scope would be influenced more by environmental factors. The data supported these expectations, thus linking this study of corporate ethics to broader discussions of choice and determinism in organizational structuring.

We believe that our finding about the key role of top management is important. But we also acknowledge that finer-grained analyses of top managers' commitment to ethics will be required in the future. Although executives may be committed to ethics in and of itself, they may also have more pragmatic, instrumental interests in ethics (Jones, 1995). Future research should distinguish different types of top management commitment to ethics and the consequences of those different types.

\section{Study Limitations}

Earlier, we addressed the possibility of bias arising from socially desirable responses to survey items. We also acknowledge the possibility of common methods bias in some of the relationships, given that data for the dependent variables and some of the independent variables came from the same survey. We note, however, that at least for measures of ethics program scope, the relatively objective nature of the survey questions should have reduced the possibility of bias. We also note that our sample included too few firms in any single industry to allow us to investigate industry effects. Yet industry effects on ethics management certainly are possible and are worthy of future study.

Here we focus on questions of alternative causal interpretations. We considered the possibility that environmental factors might influence ethics program development indirectly by influencing top management commitment to ethics. We reanalyzed our data using LISREL (Hayduk, 1987) in order to test this possibility but found no support for this kind of mediated relationship.

We also considered the possibility of reverse causality. For example, might ethics program characteristics influence Conference Board attendance? We used lists of attendees of the three Conference Board meetings that occurred before administration of our survey to reduce the possibility of reverse causality. Also, although Conference Board attendees might represent organizations that already have broad-scope programs, our observation of the past six meetings does not support this possibility. Conference Board attendees generally represent organizations that are beginning to explore whether and how they might address ethics formally. Once such programs are in place, corporate representatives are likely to join the Ethics Officer Association and attend that organization's meetings, which are oriented toward companies with established programs. However, even if companies with established formal ethics programs attend Conference Board ethics meetings, the nature of the programhighlighting all the different things a firm can do to manage ethics-is still likely to encourage efforts to broaden the scope of an existing program.

We do not believe that the presence of an ethics program would contribute to management's awareness of the USSC guidelines. The actual ethics program documents, training programs, and policies we have seen do not refer to the USSC. Further, both the theoretical and the practitioner literatures point toward awareness of the guidelines as an influence on organizational action.

We also considered whether the existence of an ethics program might influence top management commitment. It is possible that having a broadscope ethics program would encourage top managers to talk more about ethics, but we think this is unlikely. Our formal and informal communications with ethics-responsible officers over a period of 
years suggested that even though a firm may have a broad ethics program, senior management is frequently distant from that program. Descriptive studies of corporate ethics practices also indicate low levels of top management involvement in ethics programs (Weaver et al., in press). We also see little reason to believe that having a complianceoriented program would encourage top management to show more commitment to ethics and even less reason to think that a company could develop a values-oriented program without first having executives committed to ethics.

\section{Implications for Practice and Public Policy}

Many top managers delegate responsibility for ethics management to others (e.g., legal counsel). We have listened to ethics-responsible officers' laments about their need for top management support and commitment. This study supports their concerns. Top management commitment is important for the scope and control orientation of ethics programs, especially for the latter. Such commitment is the only factor strongly associated with having a program oriented toward shared values. If companies are interested in this type of program, top managers need to communicate and demonstrate their commitment to it. They need to recognize their central role in the process of managing ethics. Many top managers may not be comfortable having a prominent role in their companies' ethics programs, preferring to leave issues of ethics to legal counsel or human resources managers. But the results of this research suggest that executive commitment to ethics has important consequences for ethics governance in companies and that managers should take their role seriously.

Finally, suggestions for public policy also follow from our finding that environmental factors and management commitment both influence ethics programs. Policies such as the USSC guidelines provide a strong incentive for firms to develop broad-scope ethics programs, so that should they get caught in misconduct, they can say that they did all of the "right" things. But merely having a broad program may not achieve ultimate public policy goals. Although we do not yet have empirical data with which to evaluate the effectiveness of one type of ethics program orientation over another, case-based research and theoretical research have suggested that values-oriented programs or combined values and compliance programs should be more effective (Paine, 1995; Treviño, 1990). Our results indicate that the orientation of ethics programs is most strongly linked to a high-level management commitment to ethics rather than to external influences. Policy ef- forts, then, might be more successful if they focus less on increasing the scope of ethics programs and more on fostering top managers' commitment to ethics.

\section{REFERENCES}

Abrahamson, E. 1996. Management fashion. Academy of Management Review, 21:254-285.

Adler, P. S., \& Borys, B. 1996. Two types of bureaucracy: Enabling and coercive. Administrative Science Quarterly, 41: 61-90.

Ashforth, B. E., \& Gibbs, B. W. 1990. The double-edge of organizational legitimation. Organization Science, 1: $177-194$.

Barbakow, J. C. 1995. The ethics patrol. Chief Executive, July-August: 58-61.

Baucus, M. S., \& Near, J. P. 1991. Can illegal corporate behavior be predicted? An event history analysis. Academy of Management Journal, 34: 9-36.

Bendix, R. 1956. Work and authority in industry. New York: Wiley.

Berenbeim, R. 1992. Corporate ethics practices. New York: Conference Board.

Bourgeois, L. J., III. 1984. Strategic management and determinism. Academy of Management Review, 9: $586-596$.

Braverman, H. 1974. Labor and monopoly capital. New York: Monthly Review Press.

Bureau of National Affairs. 1996. Prevention of corporate liability, 4(4): 14-16. Washington, DC: Bureau of National Affairs.

Business Week. 1994. Managing by values. August 1: $46-52$.

Center fог Business Ethics. 1992. Instilling ethical values in large corporations. Journal of Business Ethics, 11: $863-867$.

Chen, C. C., \& Meindl, J. R. 1991. The construction of leadership images in the popular press: The case of Donald Burr and People Express. Administrative Science Quarterly, 36: 521-555.

Child, J. 1972. Organizational structure, environment, and performance. Sociology, 6: 1-22.

Child, J. 1997. Strategic choice in the analysis of action, structure, organizations and environment: Retrospect and prospect. Organisation Studies, 18: 43-76.

Cochran, P. L., \& Nigh, D. 1987. Illegal corporate behavior and the question of moral agency: An empirical examination. In W. C. Frederick (Ed.), Research in corporate social performance and policy, vol. 9: 73-91. Greenwich, CT: JAI Press.

Covaleski, M. A., \& Dirsmith, M. W. 1988, An institutional perspective on the rise, social transformation, and fall of a university budget category. Administrative Science Quarterly, 33: 562-587.

Dalton, D. R., Metzger, M. B., \& Hill, J. W. 1994. The 
"new" U.S. Sentencing Commission guidelines: A wake-up call for corporate America. Academy of Management Executive, 8(1): 7-13.

Darlington, R. B. 1968. Multiple regression in psychological research and practice. Psychological Bulletin. 69: 161-182.

DiMaggio, P. J. 1988. Interest and agency in institutional theory. In L. G. Zucker (Ed.), Institutional patterns and organizations: Culture and environment: 3-22. Cambridge, MA: Ballinger.

DiMaggio, P. J., \& Powell, W. W. 1983. The iron cage revisited: Institutional isomorphism and collective rationality in organization fields. American Sociological Review, 48: 147-160.

Donaldson, T., \& Preston, L. E. 1995. The stakeholder theory of the corporation: Concepts, evidence, and implications. Academy of Management Review, 20: $65-91$.

Dutton, J. E., \& Duncan, R. B. 1987. The creation of momentum for change through the process of strategic issue diagnosis. Strategic Management Journal, 8: $279-295$.

Edwards, R. 1979. Contested terrain: The transformation of the workplace in the twentieth century. New York: Basic Books.

Elsbach, K. D., \& Sutton, R. I. 1992. Acquiring organizational legitimacy through illegitimate actions: A marriage of institutional and impression management theories. Academy of Management Journal, 35: 699-738.

Etzioni, A. 1961. A comparative analysis of complex organizations. New York: Free Press.

Etzioni, A. 1988. The moral dimension. New York: Free Press.

Fernandes, M. F., \& Randall, D. M. 1992. The nature of social desirability response effects in ethics research. Business Ethics Quarterly, 2: 183-206.

Finkelstein, S., \& Hambrick, D. C. 1990. Top-management-team tenure and organizational outcomes: The moderating role of managerial discretion. Administrative Science Quarterly, 35: 484-503.

Finkelstein, S., \& Hambrick, D. C. 1996. Strategic leadership top executives and their effects on organizations. Minneapolis: West.

Freeman, R. E. 1995. Presidential address. Speech presented at the annual meeting of the Society for Business Ethics, Vancouver, B.C.

Galaskiewicz, J. 1985. Interorganizational relations. In R. H. Turner \& J. F. Short (Eds.), Annual review of sociology, vol. 11: 281-304. Palo Alto, CA: Annual Reviews.

Goodrick, E., \& Salancik, G. R. 1996. Organizational discretion in responding to institutional practices: Hospitals and cesarean births. Administrative Science Quarterly, 41: 1-29.

Gouldner, A. W. 1954. Patterns of industrial bureaucracy. New York: Free Press.

Greening, D. W., \& Gray, B. 1994. Testing a model of organ- izational response to social and political issues. Academy of Management Journal, 37: 467-498.

Haas, R. D. 1994. Ethics in the trenches. Across the Board, 31(5): 12-13.

Hambrick, D. C., \& Finkelstein, S. 1987. Managerial discretion: A bridge between polar views of organizational outcomes. In L. L. Cummings \& B. M. Staw (Eds.), Research in organizational behavior, vol. 9: 369-406. Greenwich, CT: JAI Press.

Hambrick, D. C., Geletkanycz. M. A., \& Fredrickson, J. 1993. Top executive commitment to the status quo: Some tests of its determinants. Strategic Management Journal, 14: 401-418.

Hambrick, D. C., \& Mason, P. 1984. Upper echelons: The organization as a reflection of its top managers. Academy of Management Review, 9: 193-206.

Hayduk, L. A. 1987. Structural equation modeling with LISREL: Essentials and advances. Baltimore: Johns Hopkins University Press.

Hitt, M. A., \& Tyler, B. 1991. Strategic decision model: Integrating different perspectives. Strategic Management Journal, 12: 327-351.

Howard, R. 1990. Values make the company: An interview with Robert Haas. Harvard Business Review, 68(5): 132-144.

Hrebiniak, L. G., \& Joyce, W. T. 1985. Organizational adaptation: Strategic choice and environmental determinism. Administrative Science Quarterly, 30: 336-349.

Jones, T. M. 1995. Instrumental stakeholder theory: A synthesis of ethics and economics. Academy of Management Review, 20: 404-437.

Lerner, M. J. 1977. The justice: motive: Some hypotheses as to its origins and forms. Journal of Personality, 45: $1-52$.

Levi Strauss \& Co. 1997a. Our culture. Available from 〈http://www.levistrauss,com/hr_culture.html $\rangle$ (accessed October 1).

Levi Strauss \& Co. 1997b. All about L.S. \& Co. Available from (http://www.levistrauss.com/all_about.html) (accessed October 1).

Levi Strauss \& Co. 1997c. Mission, visions, aspirations. Available from 〈http://www.levistrauss.com/lsc mission.html (accessed October 1).

Light, R. J. 1971. Measures of response agreement for qualitative data: Some generalizations and alternatives. Psychological Bulletin, 76: 365-377.

Meyer, J. W., \& Rowan, B. 1977. Institutionalized organizations: Formal structure as myth and ceremony. American Journal of Sociology, 83: 340-363.

Miles, R. H. 1982. Coffin nails and corporate strategies. Englewood Cliffs, NJ: Prentice-Hall.

Miller, C. 1997. Marketers weigh effects of sweatshop crackdown. Marketing News, 31(10): 1, 19.

Moorman, R. H., \& Podsakoff. P. M. 1992. A meta-analytic review and empirical test of the potential confounding effects of social desirability response sets 
in organizational behaviour research. Journal of Occupational and Organizational Psychology, 65: 131-149.

Mowday, R. T. 1982. Employee-organization linkages: The psychology of commitment, absenteeism, and turnover. New York: Academic Press.

National directory of corporate public affairs. 1994. Washington, DC: Columbia Books.

Oliver, C. 1991. Strategic responses to institutional processes. Academy of Management Review, 16: 145-179.

Ouchi, W. G. 1980. Markets, bureaucracies and clans. Administrative Science Quarterly, 25: 129-141.

Paine, L. S. 1995. Managing for organizational integrity. Harvard Business Review, 72(2): 106-117.

Paine, L. S. 1996. Moral thinking in management: An essential capability. Business Ethics Quarterly, 6: 477-492.

Powell, W. W. 1988. Institutional effects on organizational structure and performance. In L. Zucker (Ed.), Institutional patterns and organizations: 115-136. Cambridge, MA: Ballinger.

Rafalko, R. J. 1994. Remaking the corporation: The 1991 U.S. sentencing guidelines. Journal of Business Ethics, 13: 625-636.

Salancik, G. R. 1979. Interorganizational dependence and responsiveness to affirmative action: The case of women and defense contractors. Academy of Management Journal, 22: 375-394.

Scott, W. R, 1995. Institutions and organizations. Thousand Oaks, CA: Sage.

Scott, W. R., \& Mever, J. W. 1991. The rise of training programs in firms and agencies: An institutional perspective. In B. M. Staw \& L. L. Cummings (Eds.), Research in organizational behavior, vol. 13: 297326. Greenwich, CT: JAI Press.

Sherman, S. 1997. Levi's: As ye sew, so shall ye reap. Fortune, May 12: 104-116.

Simon, H. A. 1957. Administrative behavior: A study of decision-making processes in administrative organizations. New York: Macmillan.

Suchman, M. C. 1995. Managing legitimacy: Strategic and institutional approaches. Academy of Management Review, 20: 571-610.

Thomas, J. B., Clark, S. M., \& Gioia, D. A. 1993. Strategic sensemaking and organizational performance: Linkages among scanning, interpretation, action and outcomes. Academy of Management Journal, 36: $239-270$

Treviño, L. K. 1990. A cultural perspective on changing and developing organizational ethics. In R. Woodman \& W. Passmore (Eds.), Research in organizational change and development, vol. 4: 195-230. Greenwich, CT: JAI Press.
Treviño, L. K. 1993. The social effects of punishment: A justice perspective. Academy of Management Review, 17: 647-676.

Treviño, L. K., \& Ball, G. A. 1992. The social implications of punishing unethical behavior: Observers' cognitive and affective reactions. Journal of Management, 18: 751-769.

United States Sentencing Commission. 1994. Federal sentencing guidelines manual. Washington, DC: United States Sentencing Commission.

United States Sentencing Commission. 1995. Corporate crime in America: Strengthening the "good citizen" corporation. Washington, DC: United States Sentencing Commission.

Wall Street Journal. 1994. Orange \& Rockland hires Robert McGuire for ethics program. October 7: C22.

Wartick, S. L. 1992. The relationship between intense media exposure and change in corporate reputation. Business and Society, 31(1): 33-50.

Weaver, G. R. 1992. Explaining ethical structures: Transaction costs and institutional processes. Academy of Management Best Papers Proceedings: 358-362.

Weaver. G. R., Treviño, L. K., \& Cochran, P. L. In press. Corporate ethics practices in the mid-1990s. Journal of Business Ethics.

Weber, M. 1947. The theory of social and economic organization. Glencoe, IL: Free Press.

Weick, K. E. 1979. The social psychalogy of organizing. New York: Random House.

Wilkins, A. L., \& Ouchi, W. G. 1983. Efficient cultures: Exploring the relationship between culture and organizational performance. Administrative Science Quarterly, 28: 468-481.

Gary R. Weaver is an assistant professor of management at the College of Business and Economics, University of Delaware. He received a Ph.D. in management and organization from the Pennsylvania State University and a Ph.D. in philosophy from the University of Iowa. His current research interests include topics in business ethics at both the individual and organizational levels of analysis.

Linda Klebe Treviño is a professor of organizational behavior at the Mary Jean and Frank P. Smeal College of Business Administration, Pennsvlvania State University. She received her Ph.D. in management from Texas A\&M University. Her current research foruses on the management of misconduct in organizations and on organizational justice.

Philip L. Cochran is an associate professor of business administration at the Mary Jean and Frank P. Smeal College of Business Administration, Pennsylvania State University. He received his Ph.D. from the University of Washington. His current research interests include business ethics, corporate governance, and issues management. 